\title{
The estimation of semen production based on body weight and scrotal cir- cumference on PO Bull at Singosari National Artificial Insemination Center
}

\author{
L. Muthiapriani ${ }^{1)}$, E. Herwijanti ${ }^{2}$, I. Novianti ${ }^{1)}$, A. Furqon ${ }^{1)}$, W.A. Septian ${ }^{1)}$, Suyadi ${ }^{1) *}$ \\ ${ }^{1)}$ Faculty of Animal Science Brawijaya University \\ Jl. Veteran, Malang 65145, Indonesia. \\ ${ }^{2)}$ National Artificial Insemination Center, Singosari, Indonesia
}

Submitted: 18 Februari 2019, Accepted: 28 April 2019

\begin{abstract}
Ongole Crossbred cattle or more popular known as Peranakan Ongole (PO) cattle is one of local breeds cattle in Indonesia. For improving the population and genetic quality, superior bull with high capacity to produce semen is seriously required. This study aimed to find out the estimation value of semen production of PO bull based on body weight and scrotal circumference. A total sampling of 9 bull candidates of PO cattle available at National Artificial Center (NAIC) Singosari, Malang, Indonesia were used in this study. The method used was case study. Scrotal circumference was directly measured as a primary data. While body weight, semen volume, semen concentration and sperm motility were collected from BBIB Singosari from secondary data. Data was analyzed using simple linear regression. The results showed that with the limited number of samples, there is no significant correlation $(\mathrm{P}>0.05)$ between body weight and scrotal circumference on semen volume, semen concentration, and sperm motility. It was concluded that with limited number of samples involved in this study, there was no significantly on semen production based on body weight and scrotal circumference on PO bull. The suggestion was to improve the correlation value and significant result. The number of samples should be increased.
\end{abstract}

Keywords : PO bull; body weight; scrotal circumference; semen production. 


\section{INTRODUCTION}

Ongole Crossbreed cattle or more popular name for this breed in Indonesia as Peranakan Ongole (PO) cattle is one of the very important local cattle breeds in Indonesia. The cattle are very easy found and observed in overall region in Indonesia especially in Java, and more concentrated in East Java, where the highest cattle population is found in this province. Performantly the cattle are well adapted with various environment stress agents and well adapted to the very hot and high humid tropical climate, low quality of feed and some tropical parasites.

Efforts to develop beef cattle from all aspects need to be done continuously from year to year, especially for Indonesian local beef cattle. One important and urgent aspect to do is the aspect of improving the genetic quality of beef cattle. This aspect is important in order to form a productive domestic cattle population so as to be able to meet domestic meat needs. There are three major beef cattle nations that inhabit the Indonesian region, namely Ongole, Bali, and Madura along with their breeds (Kusumaningsih, 2002). The largest population of beef cattle is in the province of East Java with 4,657,567 tails. Then followed by Central Java provinces with $1,721,018$ and South Sulawesi with 1,508,401 (National Livestock Statistic, 2018). Such populations can be formed when there are efforts to develop beef cattle breeding, especially PO cattle in a sustainable manner.

Basically, the theory that developed in the community about improving the genetic quality of beef cattle is marriage between a good parent and a good male so that it will produce good offspring as well. In line with this theory, the selection of prospective elders, especially prospective males, is very important. One step that can be taken to get a good male candidate is to pay attention to the criteria for body weight and libido or the quality of prospective male sperm. The prospective body weight of the male cow must be above the average body weight of its generation in a particular region (Zurahmah and Enos, 2011).

The only way to find out the body weight of a cow accurately and also accurately is by weighing. But in certain situation and circumstances, especially in people's farms, there is rarely or even no availability of cattle scales. Therefore, there needs to be a breakthrough or other method that is considered more practical in estimating the body weight of an animal. Several previous studies conducted by Nusi et al. (2011) explained that the average body weight of male PO cattle aged 1.5 to 2 years used in the study was $272.67 \pm 26.84$ kg. Ratnawati and Affandhy (2013) also reported that the average body weight of PO cattle with dental status I0-I3 was $312.4 \pm 44.6 \mathrm{~kg}$. According to Saputra et al. (2017) the criteria for determining male candidates are observed the quality of semen, namely volume, concentration, motility and abnormalities. Male PO cattle produce semen volume of $2.1 \pm 0.7$ (cc), concentration of $800 \pm 806.9$ million / ml, motility of $53.7 \pm 24.9 \%$ and abnormalities of $9.3 \pm 2.3 \%$. According to Kumar and Srivastava (2017) there is a positive correlation between the relationship between body weight and the size of the scrotal circumference and the volume of semen, while the size of the scrotal circumference correlated with the quality of semen. This is also in line with Soeroso and Duma (2006) stating that testicular weight has a high correlation with the size of the scrotum. Adhyatma et al. (2013) added that the large size of the testis had more seminiferous tubules which would increase the number of spermatozoa. This study was objected to analysis whether the body weight and scrotal circumference have correlation to the semen production of PO bull, and therefore the semen characteristics could be estimated easily by the body weight and scrotal circumference of bull in PO cattle. 


\section{MATERIALS AND METHODS}

This research was conducts in October 2018 at National Artificial Insemination Center (NAIC), Singosari, Malang. The material used was nine PO cattle with healthy body condition and normal genitals without any consideration for variations in the age and body weight. A total of 9 bulls available at NAIC Singosari were used in this study. The age of bulls ranged from 3 to 6 years with body weight from 460 to $878 \mathrm{~kg}$. Semen collection for each bull was conducted normally once or twice per week. Feed given are elephant grass $(80.5 \%)$, silage (9\%), hay (Brachiaria decumbens) (1.2\%), and concentrates $(9.3 \%)$ at the morning and evening and drinking water is served adlibitum.

The method used in this study is a case study by measuring the scrotum circumference directly on the day when semen is not collected. Data of body weight, semen volume, sperm motility and sperm concentration were collected from secondary data available at the NAIC Singosari. Data of body weight were averaged from monthly weighing data of the bulls from January to October 2018, while data for semen production were collected from the records of semen collection during October 2018.

Scrotal circumference was measured with tool using scale measuring tape linked to the tip of wooden stick. The measuring scrotum was applied to the largest circumference of scrotum (SNI, 2015). Scrotum circumference measured on October 2018. The number of samples used were 9 PO bull at NAIC Singosari. The scrotal circumference was directly measured in the morning at 08.00-10.00 WIB and on the day that semen was not collected.
Semen production data was obtained through directly observation after semen collected process is completed. Semen production data used during the October 2018. This is adjusted by the scrotal circumference measured on that month. Semen shelter is carried out twice a week, every Monday and Thursday. The right time to do semen collection is generally in the morning, at 08.00-10.00 WIB exactly.

\section{RESULTS AND DISCUSSION}

Table 1 presents the results of descriptive statistical analysis of semen production data in prospective PO cattle studs that are not grouped by age, body weight, or size of scrotal circumference. Body weight of the bull aging from 3 to 6 years old ranged from $460 \mathrm{~kg}$ to $878 \mathrm{~kg}$. The bulls with this ages and weights are the optimum bulls used for the source genetic material from the male site, as well as the semen. Ahmad, Ahmad, Naseer, Aleem, Khan, Ashiq, and Younis (2011) reported that Sahiwal bulls reached the optimal growth of body weight and scrotal circumference in the range of age from 30 to 100 months. The mean body weight increase was more rapid from 0 to 36 months of age than from 37 to $>100$ months of age. The correlation between age and body weight was 0.91 with regression equation $\mathrm{Y}=91: 08+45: 07 \mathrm{X}$. Mean SC followed the same pattern as that of body weight during development. The correlation between age and $\mathrm{SC}$ was 0.87 with a regression equation $\mathrm{Y}=15: 38+2.01 \mathrm{X}$. They also showed close correlation $(\mathrm{P}<0.05)$ between body weight and scrotum circumference from the age of 6 to 100 months.

Table 1. Mean and standard deviation (SD) of body weight and scrotal circumferences on PO bull.

\begin{tabular}{lllllll}
\hline \multicolumn{1}{c}{ Variable } & $\mathrm{n}$ & Mean & SD & Minimum & Maximum & $(\mathrm{CV}) \%$ \\
\hline Body weight $(\mathrm{kg})$ & 9 & 720 & 131.79 & 460 & 878 & 18.30 \\
Scrotal circumference $(\mathrm{cm})$ & 9 & 40.11 & 2.80 & 36 & 42 & 6.99 \\
\hline
\end{tabular}


In Table 2 can be seen that the coefficient of diversity at the semen concentration is higher when compared to the semen volume or sperm motility. This showes that the value of semen concentration is more varied compared to semen volume or motility.

Table 2. Mean and standard deviation (SD) of semen volume, semen concentration, and sperm motility on PO bull.

\begin{tabular}{lllllll}
\hline \multicolumn{1}{c}{ Variable } & $\mathrm{n}$ & Mean & SD & Minimum & Maximum & (CV) \% \\
\hline $\begin{array}{l}\text { Volume semen } \\
\text { Sperm concentration }\end{array}$ & 9 & 4,493 & 1,559 & 0,8 & 9,6 & 32,96 \\
$\left(\mathbf{x 1 0}^{\mathbf{6}}\right)$ & 9 & 1200,651 & 501,66 & 99 & 2558 & 41,85 \\
Sperm motility (\%) & 9 & 40,416 & 17,06 & 0 & 75 & 29,52 \\
\hline
\end{tabular}

\section{Relationship between body weight and semen production}

The volume semen is semen which has been collected for each bull then measured by looking directly at the scale of the tube (Susilawati, 2011). Based on the results of the regression analysis to estimate the volume of semen by body weight in PO Bull, it was obtained the regression equation as $\mathrm{Y}=7.322-0.004 \mathrm{X}_{1}$, where $\mathrm{X}_{1}$ is body weight. The results of statistical tests show that the regression coefficient (0.475) has no significant level ( $\mathrm{P}>0.05)$. This means that the regression equation in this case cannot be used to predict the volume semen in PO bull. Based on the figures $\mathrm{R}^{2}=$ $0.226,22.6 \%$ of the variation in body weight can explain the volume semen with low level confidence, while $77.4 \%$ is influenced by other factors. According to Garner and Hafez (2000) the volume of cement produced will vary according to nation, age, body weight, and frequency of shelter.
Furthermore, Sumeidiana, Wuwuh, and Mawarti (2007) added that the volume of semen is influenced by various factors including breed, age, and body weight. The non-significant correlation in this study might be caused the limited number of samples used in this study and high value of SD especially for body weight. However, it might be clearly explained theoretically that the semen production is not directly influenced by the measure of physical appearances such as body size and weight or scrotal size, but is more directly influenced by genetic and reproductive hormone profile especially testosterone with $r=0.414(\mathrm{P}<0.05)$. In their study, reported that the correlation between scrotal circumference to semen characteristics was also low value, to semen volume $r=0.181$, to sperm motility $r=0.112$, and to sperm concentration $r=0.063$.

Table 3. Correlation between body weight and semen production on PO bull.

\begin{tabular}{lllll}
\hline Independent variable & Dependent variable & $\mathrm{R}$ & $\mathrm{R}^{2}(\%)$ & Coefecient of regression \\
\hline \multirow{3}{*}{ Body weight } & Semen volume & 0,48 & 22,6 & $\mathrm{Y}=7,322-0,004 \mathrm{X}_{1}$ \\
& Sperm concentration & 0,33 & 11.0 & $\mathrm{Y}=1657,102-0,626 \mathrm{X}_{1}$ \\
& Sperm motility & 0,65 & 42,3 & $\mathrm{Y}=108,667-0,072 \mathrm{X}_{1}$ \\
\hline
\end{tabular}


The concentration of spermatozoa per milliliter of cement is very important, because this factor is used as a determinant of the quality of semen and also determines the level of dilution (Susilawati, 2011). The results of the regression analysis to determine body weight with the concentration of spermatozoa in PO bull obtained a regression equation $\mathrm{Y}=1657,102-0,626$ $\mathrm{X}_{1}$ where $\mathrm{X}_{1}$ is body weight. The statistical test results show that the regression coefficient (0.331) has no significant effect $(\mathrm{P}>0.05)$. This means that the regression equation cannot be used to predict the semen concentration in PO bull. Based on the figures $\mathrm{R}^{2}=0.110,11 \%$ of the variation in body weight can explain the semen concentration, while $89 \%$ is influenced by other factors. Other factors that are thought to influence the semen concentration included feed nutrition, frequency of ejaculation, and climate weather.

The sperm motility is done subjectively where the assessment can be seen from the progressive movement of the spermatozoa forward. The sperm motility is very susceptible to environmental conditions, both excessive and hot environments. So that an effort is needed to protect semen from dangerous conditions or agents, before semen will undergo a further process to be analyzed (Ax, et al. 2008). Regression analysis results to determine body weight with sperm motility in PO bull obtained regression equation $\mathrm{Y}=108,667-0,072 \mathrm{X}_{1}$ where $\mathrm{X}_{1}$ is body weight. The statistical test results show that the regression coefficient $(0.650)$ has no significant effect $(\mathrm{P}>$ $0.05)$. This means that the regression equation cannot be used to predict sperm motility of PO bull. Based on the figures $\mathrm{R}^{2}=$ $0.423,42.3 \%$ of the variation in body weight can explain the sperm motility, while $57.7 \%$ is influenced by other factors. This factor is thought to be due to differences in species, age, frequency of shelter, as well as shelter, feed, and maintenance management techniques (Hafez, 2008).

\section{Relationship of scrotal circumference with semen production}

Tabel 4. Correlation between scrotal circumference and semen production on PO bull.

\begin{tabular}{lllll}
\hline Independent variable & Dependent variable & $\mathrm{R}$ & $\mathrm{R}^{2}(\%)$ & Coefecient of regression \\
\hline \multirow{2}{*}{ Scrotal circumfer- } & Semen olume & 0,103 & 1,1 & $\mathrm{Y}=6,195-0,037 \mathrm{X}_{2}$ \\
ence & Semen concentration & 0,358 & 12,8 & $\mathrm{Y}=2482,992-31,830 \mathrm{X}_{2}$ \\
& Sperm motility & 0,38 & 14,4 & $\mathrm{Y}=135,852-1,962 \mathrm{X}_{2}$ \\
\hline
\end{tabular}

The results of the regression analysis to find out the scrotal circumference with the volume of cement in PO cow studs obtained regression $\mathrm{Y}=6.195-0.037 \mathrm{X}_{2}$ where $X_{2}$ is the scrotum circumference. The statistical test results show that the regression coefficient (0.103) has no significant effect $(\mathrm{P}>0.05)$. This means that the regression equation cannot be used to predict the volume of cement in cow stud PO. Based on the figures $\mathrm{R}^{2}=0.011,1.1 \%$ of the variation in the scrotal circumference can explain the semen volume. While $98.9 \%$ is influenced by other factors. According to previous research by Dedi Yus- tendi, Dasrul and Didy (2013) the size of the scrotal circumference had a significant effect on the volume of fresh semen. The increasing size of the scrotal circumference increases the volume of fresh semen on male Ettawa grade goats. This is suspected in a study of Dedi Yustendi, et al (2013) that there were some differences in the conditions of livestock, ranging from age and body weight. Sarder (2005) added that an increase in semen volume, consistency, total motile spermatozoa cells, and concentrations of spermatozoa in semen per ejaculation were accompanied by an increase in the semen tubular ducts as a producer of 
spermatozoa through the process of spermatogenesis.

Regression analysis results to find out the scrotal circumference with the concentration of spermatoza in PO cattle obtained regression equation $\mathrm{Y}=2482.992-31,830$ $\mathrm{X}_{2}$ where $\mathrm{X}_{2}$ is the scrotum circumference. The statistical test results that the regression coefficient $(0.358)$ has no significant effect $(\mathrm{P}>0.05)$. This means that the regression equation cannot be used to predict the concentration of PO male spermatozoa. Based on the figures $\mathrm{R}^{2}=0.128,12.8 \%$ of the variation in the scrotal circumference can explain the semen concentration, while $87.2 \%$ is influenced by other factors. One of the factors that can influence the concentration of spermatozoa is the size of the scrotal circumference. The scrotal circumference yielded no significant results for the concentration of fresh semen. This is due to the existence of a scrotum circumference size category that must be met. In line with the above statement (R. L. Ax et al, 2008) added that the classification of cattle semen specimens that met the vol- ume concentration was a medium and large category of scrotum circumference.

Regression analysis results to find out the scrotal circumference with individual motility of spermatozoa in cow stud PO regression equation $\mathrm{Y}=2482.992-31,830$ $\mathrm{X}_{2}$ where $\mathrm{X}_{2}$ is the scrotum circumference. The results of the regression coefficient statistical test 0.380 have no significant effect $(\mathrm{P}>0.05)$. This means that the regression equation cannot be used to predict the motility of individual PO spermatozoa. Based on the figures $\mathrm{R}^{2}=0.144,14.4 \%$ of the variation in the scrotal circumference can explain the sperm motility. It is suspected that the size of the scrotal circumference can affect the sperm motility of PO bull. Increasing the size of the scrotum circumference and body weight will also increase the concentration of spermatozoa, the percentage of normal motility and morphology of the spermatozoa. Dedi Yustendi, et al (2013). But in this study carried out with the number of sample limited there was no groups based on the size of the scrotal circumference.

\section{Relationship between body weight and scrotal circumference with cement production}

Tabel 5. Correlation between body weight and scrotal circumference and semen production on PO bull.

\begin{tabular}{lllll}
\hline $\begin{array}{l}\text { Independent vari- } \\
\text { able }\end{array}$ & $\begin{array}{l}\text { Dependent varia- } \\
\text { ble }\end{array}$ & $\mathrm{R}$ & $\mathrm{R}^{2}(\%)$ & Coefecient of regression \\
\hline $\begin{array}{l}\text { Body weight and } \\
\begin{array}{l}\text { Scrotal circum- } \\
\text { ference }\end{array}\end{array}$ & $\begin{array}{l}\text { Volume semen } \\
\text { Concentration }\end{array}$ & 0,55 & 30,3 & $\mathrm{Y}=3,354-0,005 \mathrm{X}_{1}+0,132 \mathrm{X}_{2}$ \\
& $\begin{array}{l}\text { semen } \\
\text { Motility sperm }\end{array}$ & 0,654 & 14,5 & $\mathrm{Y}=2317,562-0,319 \mathrm{X}_{1}+21,980 \mathrm{X}_{2}$ \\
& & & $\mathrm{Y}, 7$ & $\mathrm{Y}=95,602-0,078 \mathrm{X}_{1}+0,435 \mathrm{X}_{2}$ \\
\hline
\end{tabular}

The results of the regression analysis to determine body weight and scrotal circumference to the semen volume of PO cattle obtained by the equation $\mathrm{Y}=33.54-0.005$ $\mathrm{X}_{1}+0.132 \mathrm{X}_{2}$ where $\mathrm{X}_{1}$ is body weight while $\mathrm{X}_{2}$ is the scrotum circumference. The results of the regression coefficient statistical test (0.550) have no significant effect $(\mathrm{P}>0.05)$. This means that the regression equation cannot be used to predict the vol- ume of cement in cow stud PO. Based on figures $R^{2}=0.303,30.3 \%$ of the variation in body weight and scrotal circumference can explain the volume of semen. While $69.7 \%$ is influenced by other factors. The implementation of maintenance management can also be one of the contributing factors. Management of maintenance of PO cattle in BBIB Singosari is done well so as to produce superior bull. BBIB Singosari is 
located on a high land so that it has a temperature and humidity which is very possible for PO cattle growth. Furthermore, Dedhi Yustendi, et al (2013) argues that the addition of katuk leaf meal in feed had significant effects $(\mathrm{P}<0.05)$ on body weight gain and scrotal circumference of Ettawa grade goat.

The results of the regression analysis to determine body weight and scrotal circumference with semen concentration of PO cattle obtained regression equation $\mathrm{Y}=$ $2317,562-0,391 X_{1}+21,980 X_{2}$ where $X_{1}$ is body weight while $X_{2}$ is the scrotum circumference. The results of the regression coefficient statistical test (0.380) have no significant effect $(\mathrm{P}>0.05)$. This means that the regression equation cannot be used to predict the cement concentration of $\mathrm{PO}$ studs. Based on figures $\mathrm{R}^{2}=0.145,14.5 \%$ of the variation in body weight and scrotal circumference can explain the semen concentration. While $85.5 \%$ is influenced by other factors.

The results of regression analysis to determine body weight and scrotal circumference with sperm motility of PO bull obtained a regression equation $\mathrm{Y}=95.602$ $0.078 \mathrm{X}_{1}+0.435 \mathrm{X}_{2}$ where $\mathrm{X}_{1}$ is body weight while $\mathrm{X}_{2}$ is the scrotum circumference. The results of the regression coefficient statistical test $(0.654)$ have no significant effect $(\mathrm{P}>0.05)$. This means that the regression equation cannot be used to predict the motility of individual PO spermatozoa. Based on the figures $\mathrm{R}^{2}=0.427$, $42.7 \%$ of the variation in body weight and scrotal circumference can explain the motility of individual spermatozoa, while $57.3 \%$ is influenced by other factors. Other factors that can affect the size of the scrotum circumference are energy levels in feed and differences in genotype in livestock. Foods that have a high energy content can cause precipitation of fat in the scrotum cavity Ahmad, Ahmad, Naseer, Aleem, Khan, Ashiq, and Younis (2011).

\section{Conclusions}

Based on the results it was concluded with limited number of sample involved in this study, that there was no relationship between body weight and semen production, then scrotum circumference with semen production, as well as both body weight and scrotal circumference to semen production. Thus, there is no formula that can be used to predict semen production based on body weight and scrotal circumference on PO bull.

\section{Acknowledgement}

This paper preparation is supported by USAID through Sustainable Higher Education Research Alliances (SHERA) Program - Center for Collaborative Research Animal Biotechnology and Coral Reef Fisheries (CCR ANBIOCORE). The authors thank to Prof. Dr. Bambang Purwanta, DVM as Leader of ANBIOCORE (Animal Biotechnology and Coral Reef Fisheries) under coordination of SHERA (Sustainable Higher Education Research Alliances) USAID for supporting collabpration and publication funding, Prof. Dr. Erdogan Memmili, DVM, PhD, University of Missisippi, USA for some valuable suggestion during preparing and conducting the study. We thank also very much the Director and Team of National Artificial Insemination Center at Singosari, Malang-Indonesia for providing data of semen production for $\mathrm{PO}$ bull and direct data collecting during semen collection.

\section{References}

Adhyatma, M., Nurul Isnaini dan Nuryadi. 2013. Pengaruh Bobot Badan Terhadap Kualitas dan Kuantitas Semen Sapi Simmental. J. Ternak Tropika, 14(2), 53-62

Ahmad E, N Ahmad, Z Naseer, M Aleem, M Sarwar Khan, M Ashiq, M Younis. 2011. Relationship of age to body weight, scrotal circumference, 
testicular ultrasonograms, and semen quality in Sahiwal bulls. Trop Anim Health Prod., 43(2011), 159-164. DOI 10.1007/s11250-010-9668-1

Ax, R.L, M.R. Dally, B.A. Didion, R.W. Lenz, C.C. Love, D.D. Varner, B. Hafez and M.E. Bellin. 2000. Semen Evaluation. In: Hafez ESE and B. Hafez Editor. Reproduction in Farm Animal. 7th ed. USA: Lippincot Wiliams and Wilkins

Badan Standarisasi Nasional. 2008. Bibit Sapi Potong - Bagian 5: Peranakan Ongole. BSN, Jakarta.

Direktorat Jenderal Peternakan dan Kesehatan Hewan. 2018. Pendataan Sapi Potong, Sapi Perah, dan Kerbau. Kementerian Sumberdaya Genetik Ternak. Deptan, Jakarta

D.L. Garner and E.S.E. Hafez. 2000. Spermatozoa and Seminal Plasma. In: Hafez ESE and B. Hafez Editor. Reproduction in Farm Animal. $7^{\text {th }}$ ed. USA: Lippincot Wiliams and Wilkins. P.165-187

Hafez, E.S.E. 2007. Artificial Insemination. In: Reproduction in Farm Animals. Hafez, E.S.E. (Ed.) $8^{\text {th }}$ ed. Lea \& Febiger, Phialadelphia. P.405

Hafez ESE and Hafez B. 2008. Reproductive Cycle in Farm Animals, $7^{\text {th }}$ ed. Lippincott Williams and Wilkins, Philadelphia, USA, pp. 55-67.

Kumar, S., and S. Srivastava. 2017. Testicular Biometry and Its Correlation with Body Weight and Semen Output in Murrah Bull. Buffalo Bulletin (January-March 2017) (36):1

Nusi, Musrifah., Ristianto Utomo dan Soeparno. 2011. Pengaruh Penggunaan Tongkol Jagung Dalam Complete Feed dan Suplementasi
Undergraded Protein Terhadap Pertambahan Bobot Badan dan Kualitas Daging Pada Sapi Peranakan Ongole. Buletin Peternakan, 35(3), 173-181.

Ratnawati, D. \& Affandhy, L. 2013. Performan reproduksi sapi jantan dengan pakan berbasis limbah sawit. Prosiding Seminar Nasional Teknologi Peternakan dan Veteriner "Inovasi Teknologi Peternakan dan Veteriner Berbasis Sumber Daya Lokal yang Adaptif dan Mitigatif terhadap Perubahan Iklim" (h.49-52) Medan: 3-5 September 2013

Saputra, D.J., M.N. Ihsan dan N. Isnaini. 2017. Korelasi Antara Lingkar Skrotum Dengan Volume Semen, Konsentrasi dan Motilitas Spermatozoa Pejantan Sapi Bali. Jurnal Ternak Tropika, 18(2), 47-53.

Soeroso dan Y. Duma. 2006. Hubungan Antar Lingkar Skrotum Dengan Karakteristik Cairan dan Spermatozoa Dalam Cauda Epididimis Pada Sapi Bali. J. Indo. Trop. Anim. Agric., 31(4), 219-223).

Sumeidiana, I., S. Wuwuh., dan E. Mawarti. 2007. Volume Semen dan Konsentrasi Sperma Sapi Simmental, Limousin, dan Braman di Balai Besar Inseminasi Buatan Ungaran. Jurnal Indon. Trop. Anim. Agric., 32(2), 132-134.

Susilawati, Trinil. 2011. Spermatology. UB Press: Malang.

Yustendi, Dedhi., Dasrul., and Didy Rachmadi. 2013. The Addition of Katuk Leaf Meal (Saurupus androgynus L. merr) in Feeds on Body Weight and Scrotal Circumference on Male Ettawa Grade Goats. Agripet Journal, 13(2), 7-14 